\title{
Inequitable distribution of green public space in the Mexico City: an environmental injustice case
}

\section{Distribución inequitativa del espacio público verde en la Ciudad de México: un caso de injusticia ambiental}

\author{
Rafael Fernández-Álvarez*
}

\begin{abstract}
This article presents an analysis of the distribution of green public spaces (GPS) in Mexico City as an urban environmental injustice case. Using spatial and demographic data, a Park Need Index (PNI) was calculated for the 16 boroughs of the city. Results show that distribution of GPS is directly correlated with demographic features usually present within low socioeconomic sectors of the city. Such findings align with the Environmental Justice Theory postulation that urban environmental amenities are inequitably distributed against marginal populations.
\end{abstract}

Keywords: Green Public Space, Environmental Justice, Environmental Social Scienc, Mexico City.

\section{Resumen}

Este artículo presenta un análisis de la distribución de espacios públicos verdes (EPV) en la Ciudad de México como un caso de injusticia ambiental urbana. Se utilizan datos espaciales y demográficos, asimismo, para llevar a cabo este análisis se calculó un Índice de Necesidad de Parques (INP) para las 16 delegaciones de la ciudad. Los resultados muestran que la distribución del EPV está directamente correlacionado con las características demográficas de los sectores socioeconómicos bajos de la ciudad. Estos hallazgos se alinean con la postulación de la Teoría de Justicia Ambiental en el sentido de que los servicios ambientales urbanos se distribuyen inequitativamente con respecto a las poblaciones marginadas.

Palabras clave: espacio público verde, justicia ambiental, ciencias socioambientales, Ciudad de México.

*School of Human Evolution and Social Change, Arizona State University, e-mail: rfernan6@ 


\section{Introduction}

This research addresses the quantitative and qualitative dimensions of green public space (GPS) in Mexico City as a case of environmental injustice. The article begins with a review of a set of relevant studies on GPS distribution and access in order to establish a theoretical framework, methodology, and a background for the presented analysis. The quantitative account of GPSs in Mexico City is presented based on Environmental Justice studies contending that urban amenities (e.g. parks) are unevenly distributed and often biased against marginal populations (Bolin et al., 2000; Boone et al., 2009; Carruthers, 2008; Chiesura, 2004).

Methodologies proposed by Boone et al. (2009) and Talen (2010) to assess the socioeconomic status of population vis-à-vis distribution of GPSs were applied. Using data provided by the Environment and Land Management Agency for the Federal District (in Spanish, Procuraduría Ambiental y del Ordenamiento Territorial del Distrito Federal, PAOT) and National Institute of Statistics and Geography (in Spanish, Instituto Nacional de Estadística y Geografía, Inegi), a series of maps were created to show Mexico City's uneven distribution of GPSs in relation to the socioeconomic status or marginality levels of its population.

GPS maps presented in this work comprise only a selection of features included in data sets provided by governmental institutions due to the fact that official maps do not follow methodological criteria established in the Environmental Statement for the Federal District (NADF-006RNAT-2004). The main difference between previous maps and those offered in this work is the criteria used to determine what is and what is not GPS. According to Mexico City Environmental Law, GPSs should be, in fact, public. All spaces accounted as GPSs for this research were contacted or visited to ensure the actual public character of each site. Whereas official documents considered airports, military stations, prisons and penitentiaries, private universities gardens, cemeteries, and even shopping malls as GPSs, this analysis focused only on spaces open to the general public for the purpose of leisure, physical activity, or any other not-for-profit activities.

In addition, the article presents the basic socio-demographic deeply differentiated characteristics of Mexico City's population (Aguilar et al., 2003) vis-à-vis GPS. Given that the most common form of GPS in Mexico City is parks (Wakild, 2007), a suit of variables proposed by the Population National Commission (in Spanish, Comisión Nacional de Población, Conapo) were integrated in the creation of a Park Need Index (PNI). Results shows that GPS distribution is biased against young 
population with low levels of education and high levels of poverty living in densely populated areas.

\section{Green public space and environmental injustice in the city}

Rodgers et al. (2012) documented processes of urbanization on an unprecedented scale in Latin America. In accordance with reports by international institutions such as the UN, WHO and World Bank, the authors confirmed that Latin America is the developing world's most urbanized region, with over $75 \%$ of its population currently residing in towns and cities. Hence, urban studies in the region have thrived focusing on the overall urban quality of life with a clear emphasis on urban inequality, widely recognized as central to many of the most pressing challenges in cities of the South (Samara et al., 2012). A robust body of Latin American literature regarding urban studies has investigated instances of environmental injustices in Mexican cities (Carruthers, 2008; Hardoy et al., 2013; Satterthwaite, 2003). Furthermore, urban environmental services and their contributions to air, soil, water, and general human and non-human wellbeing quality studies have been favored extensively in the region (Bigio and Dahiya, 2004; Coolidge et al., 1993).

Environmental justice research has examined the correlations between race and class and the equitable distribution of environmental risk as well as access to environmental amenities (Bolin et al., 2000) with the main objective to identify "who gets what and why" (Turner and Wu, 2002: 4). Considering the recurrent uneven distribution of environmental amenities and hazards in cities around the world (Schweitzer and Stephenson, 2007), environmental justice theory postulates that the distribution of urban risks and benefits are disproportionally biased against non-white minorities (environmental racism) and lower socioeconomic status population (environmental classism). This theoretical assumption is well-suited to study green space in Mexico City as all 16 boroughs comprising the Mexican Federal District feature considerable economic, social, and demographic differences (Aguilar and Mateos, 2011; Mier-yTerán et al., 2012). The question is if and which socio-demographic characteristics are influential in the distribution of green space in Mexico City, as suggested by environmental justice research.

It is important to underline that environmental justice extends beyond socio-spatial patterns. It has been proposed that incorporating three dimensions of justice: distribution, recognition, and procedure is the most suitable way to accomplish a "richer, multidimensional understanding of the different ways in which environmental (in)justice and space are coconstituted" (Walker, 2009: 24). Therefore, environmental justice schol- 
ars have concluded that, in order to fully understand what justice is, it is necessary to analyze the legal, economic, historic, cultural, social, and political processes that result in urban landscapes (Schlosberg, 2004).

For the particular case of GPS studies, there exists a general scientific consensus that "besides many environmental and ecological services, urban nature [commonly in the form of parks] provides important social and psychological benefits to human societies, which enrich human life with meanings and emotions" (Chiesura, 2004: 130). In Mexico, studies have been conducted in the states of Veracruz (Hernández-Bonilla, 2005), Nuevo Leon (Flores-Alanís, 2005), Puebla (Gante-Cabrera de and Rodríguez-Acosta, 2009), State of Mexico (Avilés and Chaparro-Gutiérrez, 2010) and Mexico City (Flores-Xolocotzi et al., 2010) to assess distribution, access, and uses of parks and other forms of GPS. Most of the scientific work regarding this topic in Mexico inclines towards a natural scientific/technical approach. Therefore, a number of urban environmental management manuals and taxonomic descriptions of the flora and fauna of the city are available; however, the lack of studies analyzing the interface between human and non-humans with the environment is noticeable. In the case of Mexico City, data clearly shows green spaces are unevenly distributed; nevertheless, there is no information regarding green space distribution per habitant in relation to specific socio-demographic characteristics. International environmental justice literature offers abundant instances of research investigating on GPS and the correlation between quality of life in urban contexts. Parks have been identified as key components for a livable city (Garvin, 2011). ${ }^{1}$

Spatial analysis of distribution and access to GPS is commonly present in the literature given the fact that the vast majority of research is based on the observation that urban infrastructure is not evenly or equitably distributed in cities (Low et al., 2005). Consequently, assessing who gets what appears to be one of the main objectives of research done for the past ten years. The methodology to analyze the spatial features of GPS can be divided in two categories. The first category includes research that focuses entirely on analyzing the quantitative spatial data available for a given city without including its human dimension (Aziz and HishamRasidi, 2014; Bjerke et al., 2006; Bowler et al., 2010; Cao et al., 2010; Nicholls, 2001). In a sense this type of research obscures the historical, social, and political extent of space and its use in cities. Functionalist or deterministic research lacks important qualitative data useful to identify actors and motives for urban planning and development. On the other

\footnotetext{
${ }^{1}$ However, occurrences of aversion to parks have also been documented (Brownlow, 2006; Madge, 1997). When neglected in their maintenance or security, parks can become a hub for crime and a source of fear (Davis, 1999).
} 
hand, there is also research incorporating both quantitative and qualitative data to answer questions of inequality and environmental justice.

For example, Boone et al. (2009) presented a hybrid study of urban parks in Baltimore, MD. Their main objective was to examine the distribution of parks as a socio-environmental injustice. Authors measured "potential park congestion as an equity outcome measure" (Boone et al., 2009: 767) using a park congestion indicator (PPC), defined as "the number of people per park acre (PPA) in a given park service area (PSA) if every resident were to use the closest park" (Boone et al., 2009: 772). In addition, as a social component of their research authors included a historical-process analysis in order to expose the possible drivers responsible of park distribution and access patterns. Boone et al. (2009: 783) concluded that

the story of parks in Baltimore illuminates the complex interactions between race and [urban] planning where efforts to segregate the city fueled fear and ignorance, and consequently white and later middle-class black flight to the suburbs, along with population and economic decline in the core [...] Baltimore is now living and struggling with the legacies of segregation and environmental injustice.

Without fetishizing spatial data, authors' conclusion casted light over the social production of environmental injustices. Studies offering quantitative data coupled with an analysis of qualitative evidence have had documented impact on public policy and other decision making processes in cities (Pincetl, 2003). For example, Sister et al. (2009) research goal was to develop decision-support tools to improve park policies, which could generate better funding allocation based on democratic and equitable principles. To do so, authors traced the historical emergence of parks in their research areas and the evolution of spatial uses/practices based on demographic features such as race and gender. Another significant illustration of merging qualitative and quantitative data into the creation of scenarios and criteria for governance is the work of (Pincetl and Gearin, 2005). Authors examined patterns of environmental services unequal distribution produced by years of social, economic, and cultural development biased against minorities. Setting the historical, geographical, and institutional context in which urban green space emerges is what allowed these authors to contextualize data in order to create useful tools for governance. Thus, this article aims to create a bridge between environmental and social studies in devising an approach that accounts for both quantitative and qualitative dimension of green public spaces in Latin American urban areas. 


\section{The quantitative dimension of green public space in Mexico City}

In 2009, the Environment and Land Management Agency for the Federal District ${ }^{2}$ (PAOT) presented a series of maps showing different aspects of environmental conditions in Mexico City including environmental risks, land uses, irregular settlements locations, and green areas distribution per habitant among others. ${ }^{3}$ Drawing from data provided by the Inegi and PAOT, using QGiS 2.4, this article presents a new map of green public space distribution per habitant per census tract. Inegi provided GPS data in the form of polygons including 15 urban features (table 1). However, not all of them represented GPS. For example, cemeteries, shopping centers, health care centers, some bodies of water, ${ }^{4}$ private edifications with green spaces, schools, markets, government palaces, electric substations, and temples are not open to the general public. Therefore, those features were not included in the present analysis. Moreover, some sports facilities and other recreational facilities were included after I corroborated their public status. ${ }^{5}$

Given the fact that a substantial number of features were not included in the creation of this new map, there exists a noticeable difference between the official maps by local governments and mine regarding green public space distribution. However, the original and most significant attributes of the map remain the same: the green area per capita map shows five different tonalities of green ranging from the lowest to the highest availability of green space; the lightest green represents the areas with less $\mathrm{m}^{2}$ of green space per resident $\left(0-2.5 \mathrm{~m}^{2} / \mathrm{hab}\right)$ compared to the darker green showing the areas with higher per capita green space (20-22 or more). The present map is also representative of the unequal distribution of green public space among boroughs in Mexico City as it shows green space concentration in the southwest and center. East areas of the city are disproportionally "gray" or lacking green space (map 1). The category of urban green area is defined in the Environmental Statement for the Federal District NADF-006-RNAT (GDF, 2002) as:

${ }^{2}$ PAOT is a decentralized institution that functions as an ombudsman between Mexico City's population, boroughs' [local] administrations, private parties, and the federal government. Its purpose is to mediate conflicts and to generate socio-environmental information useful towards proper governance of the city.

${ }^{3}$ Maps available at <http://www.paot.org.mx/contenidos/paot_docs/GEO_DATO2/menu.php>

${ }^{4}$ According to Inegi, 43 out of 45 rivers originally located in Mexico City have been piped. Infrastructure nearby non-piped areas of rivers and lakes is federal property and access is restricted (Tortolero, 2000). Lakes and ponds located inside public parks or conservation land are public. For this analysis, if bodies of water were located inside parks they were geo-referenced as parks.

${ }^{5}$ I visited the sites or called their administrative offices asking for this specific information. 
Any surface covered with natural or induced vegetation, located on public property of the Federal District, and referred to in any of the categories provided in Article 87 of the Environmental Law of the Federal District. This category includes parks, gardens, garden or tree-lined squares, planters, plant cover any areas on public roads (roundabouts, medians, trees lining), avenues and groves, headlands, mountains, hills, natural grasslands, and rural areas for forestry production or ecotourism services, canyons and areas of aquifer recharge (Environmental Law of the Federal District, 2002, 14; translation by author).

This overly generous and clearly lax definition of GPSs by Mexico City's governments serves to overstate the actual amount of GPS available in the city. Figures presented by previous administrations did account for private spaces, regardless of the contradictory official definition of GPS. As mentioned earlier, administrations have been using international standards to measure gains on GPS provision. For the Mexican capital governments, it has been of utter importance to project a progressive image. The current administration is following a questionable criterion by considering spaces with less than $160 \mathrm{~m}^{2}$ of vegetated areas established as the minimum for an urban space to be considered a GPS - according to the Article 88 bis of the Mexico City Environmental Law (GDF, 2002). Despite the fact that urban environmental governance in Mexico has shown positive advances since the late 1980s (Schteingart, 1989), current official quantitative reports on GPS provision in Mexico City are instances of local administrations trying to deceive the public by making up numbers that do not align with terms defined by local laws. Airports, military stations, prisons and penitentiaries, private universities gardens, cemeteries, and even shopping malls were considered GPSs in Mexico City reports whereas they are not included in this analysis (table 1). As an antecedent of this methodological inconsistency, (Rivas-Torres, 2005) reported that more than $44 \%$ of the spaces considered as GPS were only "grassed", agricultural areas or not at all vegetated public spaces.

In addition to the distribution of green space among boroughs in the city, it is important to identify the specific socio-demographic attributes of those areas without green areas. Following the socio-spatial research by (Mier-y-Terán et al., 2012) in Mexico City regarding urban poverty, residential segregation, and public space, a map for this article was created using the Population National Commission (Conapo) ranks and identified the neighborhoods (in Spanish, colonias) with medium-high (yellow), high (red) and very high (dark red) poverty levels in Mexico City (map 2). Conapo ranks refer to a function that accounts for four different socioeconomic variables: education levels, access to medical services, housing conditions (i.e. owning or leasing properties, number of inhabitants per residence, etc.), and access to residential services such 
as sewer and potable water. We propose the creation of a park need index based on Conapo's rankings for two fundamental reasons. On the one hand, Mier-y-Terán et al. (2012) previous work on urban poverty, segregation, and public space in Mexico City showed that the Mexican federal government uses these rankings to assess marginalization as an official standard to classify boroughs and neighborhoods or colonias. On the other hand, also according to Mier-y-Terán (2012: 127), Conapo’s rankings are best suited for spatial analysis given the "ample number of socio- demographic variables accounted for and its rigorous and systematic procedures to determine population's marginality". In short, Conapo's rankings take into consideration the largest number of variables to determine urban marginality using a reliable method; hence, it is the best proxy for our analysis. If compared to the previous map showing the distribution of green areas, it is clear that the southeast part of the city is not only an area with less green space but also the one with the highest levels of poverty.

Based on this simple observation, it can be deduced that the need for parks has to be measured based on socioeconomic features of the population and not GPSs distribution alone - as the correlation is evident. For instance, the borough of Iztapalapa shows particularly high levels of poverty that have been associated with insufficient or non-existent basic urban infrastructure, substandard housing, high levels of unemployment or underemployment, and social stigmatization (Mier-y-Terán et al., 2012). Furthermore, as showed in map 2, Iztapalapa also presents a very low concentration of green public spaces, ${ }^{6}$ an essential urban amenity.

The concentration of green public spaces in Mexico City is evident. Nevertheless, a detailed account of the socio-economic characteristics of those areas in the city enduring the lowest levels of GPS concentration was lacking. Therefore, using census data, Inegi's GPS data and Conapo rankings a Park Need Index (PNI) for Mexico City was created. The PNI was used in this article as a proxy for urban socio-environmental injustice. It is important to highlight that, as reported by Kitchen (2012), parks are not necessarily an amenity for all dwellers as their characteristics can differ significantly. Furthermore, I acknowledge that lack of parks is not as adverse as lack of potable water. However, based on decades of research establishing the importance of social and environmental services provided by green public spaces, authors have argued that biased provision of urban amenities against marginal populations is a symptom of a struc-

${ }^{6}$ PAOT's and Inegi's spatial data contains GPS features in the form of polygons. Therefore, using QGIS centroids were generated out of those polygons in order to transform them into points. Furthermore, I used the points in polygons tool to calculate an exact number of points per census block. I used this number to generate the park need index as well. 
tural condition that restricts pauperized urban dwellers from inhabiting livable urban spaces (Heynen et al., 2006; Loughran, 2014).

Needs-based assessments of parks have also been conducted in the past aiming to address issues of equity rather than equality ${ }^{7}$ (Talen, 2010). Following Boone's et al. (2009) and Talen's (2010) research, this article presents the Park Need Index as description of socio-economic and environmental characteristics of different areas in the city (table 2). Using Jenks natural breaks, variables were divided into five classes and then each census tract was assigned a corresponding value from one (very high need) to five (very low need). map 2 shows the summed values of all variables for the entire Federal District. Results show that there is a distinct lack of parks in the large majority of Mexico City's boroughs given the proposed variables. Furthermore, it is evident that some boroughs such as Coyoacan and Miguel Hidalgo — both with very low levels of poverty - are currently enjoying a higher number of parks. In fact, $77 \%$ of census tracts in Mexico City presented a very high need for parks and only $2 \%$ a very low need for parks given the used criteria for the analysis. In the case of "very low need tracts" 1005 were concentrated in areas with very low poverty levels. ${ }^{8}$

The contrasting distribution of parks in Mexico City is noticeable in an overall sense. As a further matter, if addressed in detail, the socioeconomic characteristics of boroughs are correlated to a lack of parks. In areas with low income, less educated and younger people parks are scant. In contrast wealthy, older, and more educated populations have numerous parks available; yet, the use of parks in affluent areas of developed countries like the USA have been reported to be rarely used compared to marginal areas (Heynen et al., 2006). Heynen et al. (2006: 12) indicated that: "As with other housing amenities, households with higher incomes tend to have greater disposable resources that can be used for tree planting and maintenance. Hence, upper income residences tend to have more, and better maintained, canopy cover on their properties" — and, as a result, less need for a green public space. Likewise, several authors have published research on developing countries and its urban populations unveiling the enormous gap between wealthy and marginal populations'

${ }^{7}$ According to (Oliffe and Greaves, 2011), equity involves trying to understand and provide people with what they require to fulfill their necessities. In contrast, equality aims to guarantee that everyone gets the same things in order to fulfill their necessities. Furthermore, according to the Canadian Sex- and gender-based analysis (SGBA) research center: "Like equity, equality promotes fairness and justice, but it can only work if everyone starts from the same place and needs the same things". Given that Mexico is a deeply differentiated country, equitable policies would work better, particularly in the case of provision of urban amenities.

${ }^{8}$ Census tracts were used because Conapo's and PAOT's data sets are not available at the block group level. 
accessibility to private recreation centers for exercising and leisure; seclusion and a sense of exclusivity has been reported to be preferred over public spaces by the most affluent urban populations, whereas minorities and marginal groups are constantly demanding green public spaces (e.g. Connell, 1999; Janoschka and Borsdorf, 2004).

\section{Map 1 \\ Green public space distribution in the Distrito Federal per census tract}

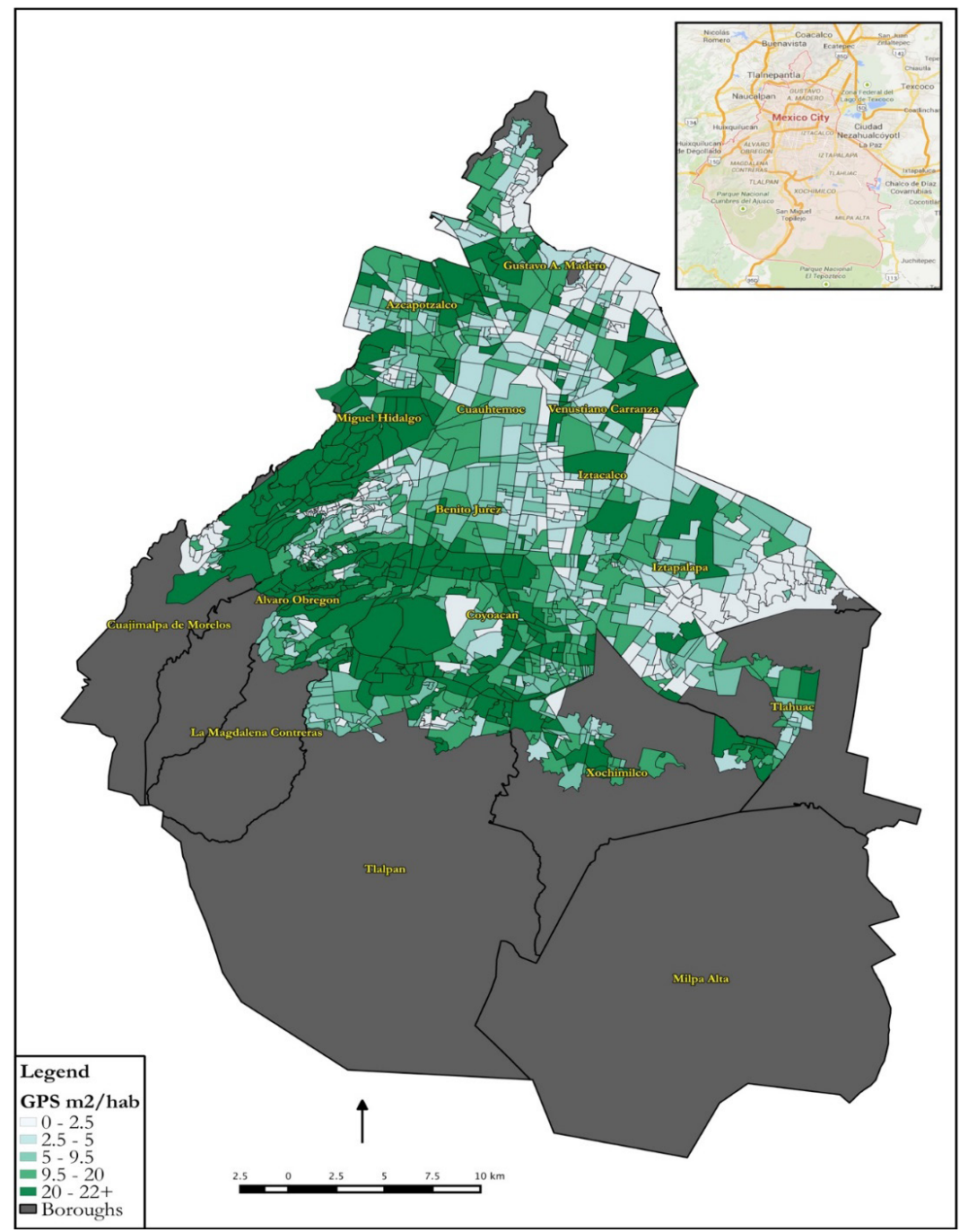

Source: Author's elaboration, 2015. 
Table 1

Green public spaces features account for distribution analysis

\begin{tabular}{llll}
\hline \multicolumn{2}{c}{ Green } & \multicolumn{1}{c}{ public spaces } \\
Feature number & \multicolumn{1}{c}{ Type } & \multicolumn{1}{c}{ Accounted for analysis } \\
\hline 1 & Median strip & Public & Yes \\
2 & Cemetery & Private & No \\
3 & Shopping center & Private & No \\
4 & Health care center & Private & No \\
5 & Edification & Private & No \\
6 & School & Private & No \\
7 & Sports facilities & Private/Public & In some instances \\
8 & Recreational facilities & Private/Public & In some instances \\
9 & Market & Private & No \\
10 & Government palace & State & No \\
& & Owned/Private & \\
11 & Plazas & Public & Yes \\
12 & Green Area & Public & Yes \\
13 & Electric substation & State & No \\
& & Owned/Private & \\
14 & Water & State & No \\
& & Owned/Private & \\
& Temple & Private & No \\
\hline
\end{tabular}

Source: Compilation and categorization by author, 2015. 


\section{Map 2 \\ Poverty levels and GPS centroids per colony}

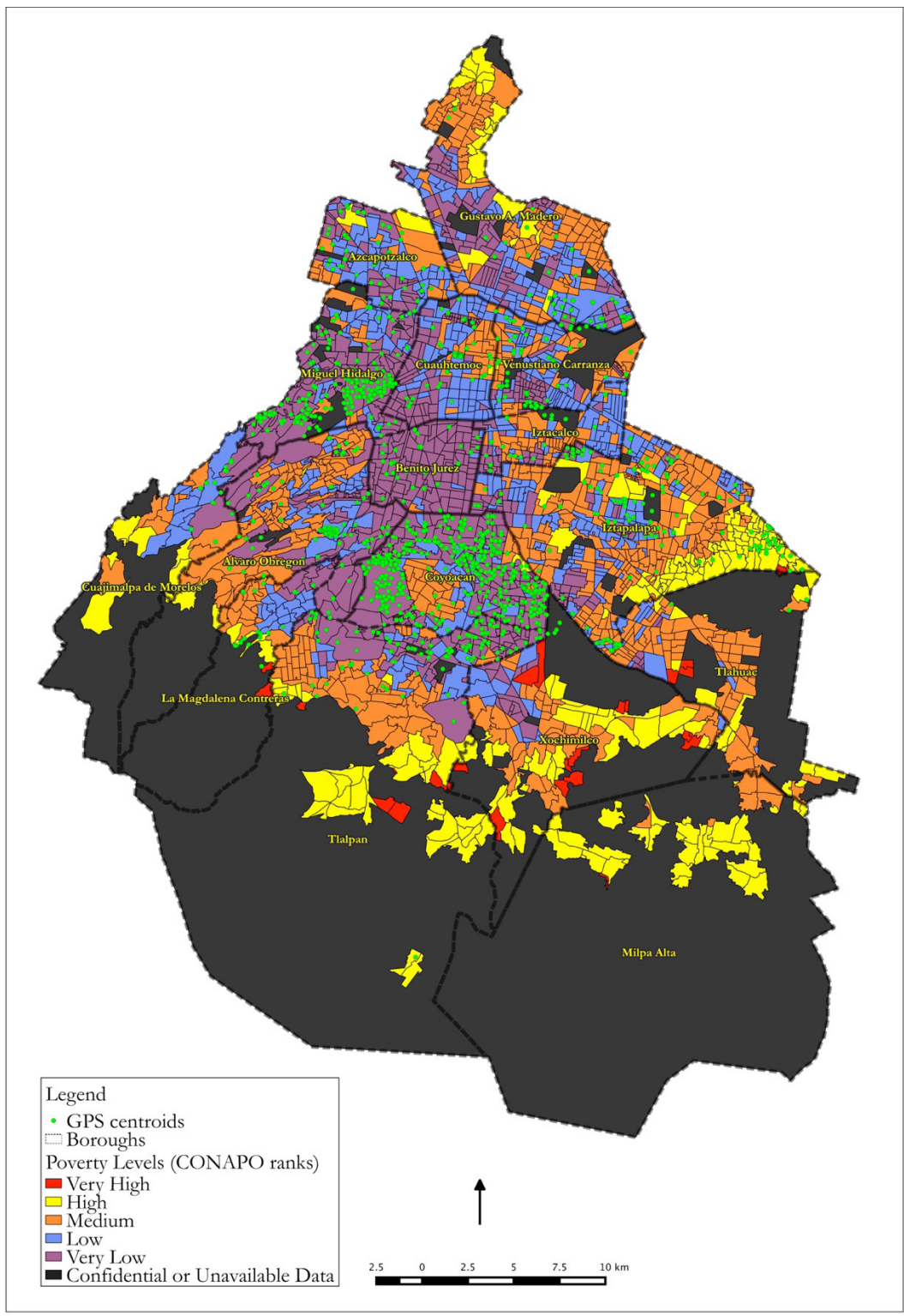

Source: Author's elaboration, 2015. 


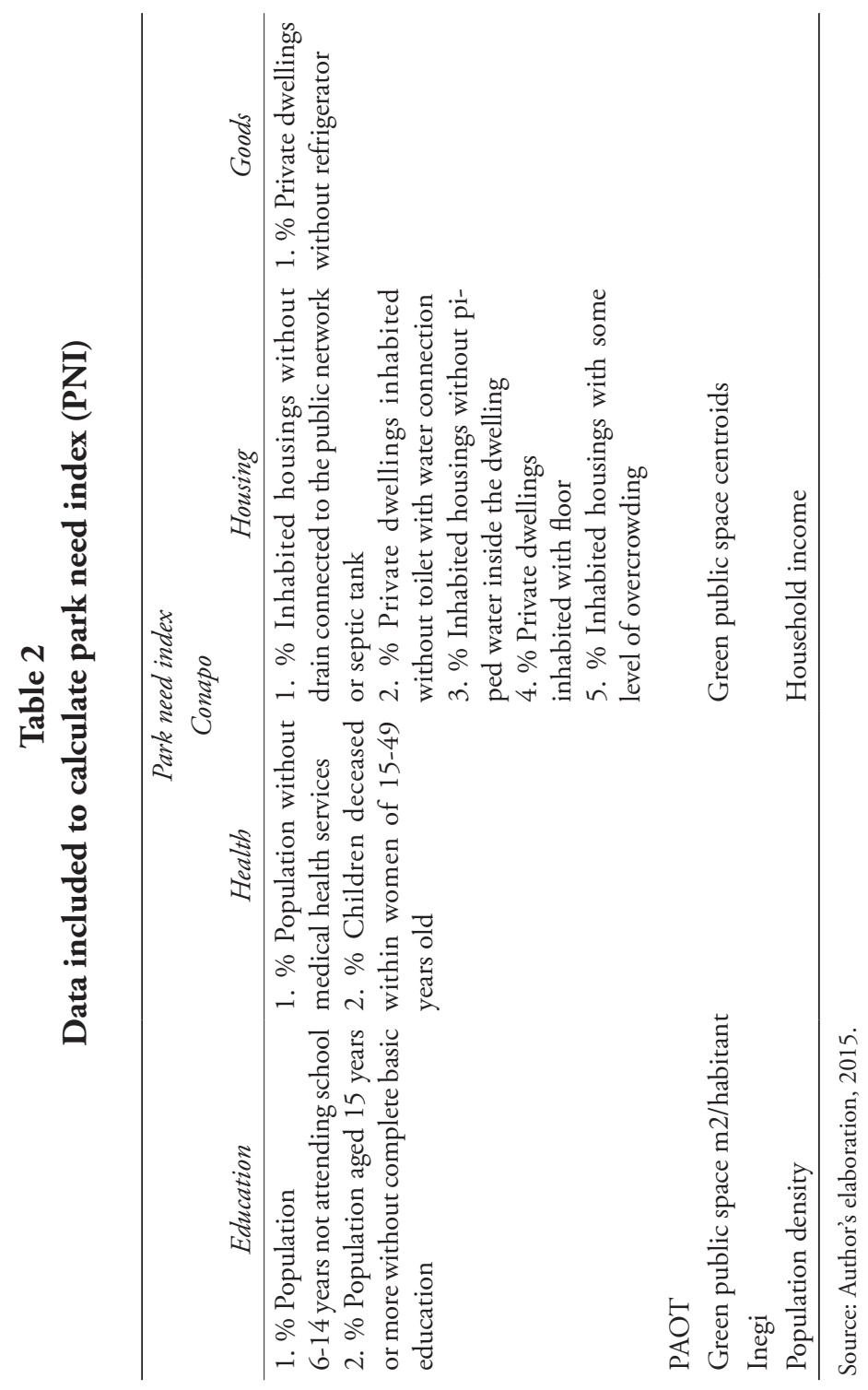




\section{A socio-environmental analysis of green public spaces in Mexico} City

Regardless of the current inequitable distribution of green public spaces (map 5), there is an absence of academic and political conversation regarding the injustices of disproportionate allocation of green spaces to an extremely small population group in mexican urban contexts. It is rather urgent to determine the guidelines that will inform the creation of parks in Mexico City based on equity over equality criteria. Equity in the distribution of GPSs has been discussed in the past (Nicholls, 2001) and regardless of its clearly subjective nature, open to multiple, sometimes competing, interpretations (Symons, 1971) there exists a standard adoption of the concept in urban contexts (Wicks and Crompton, 1986: 204). Nicholls (2001) explained:

A compensatory, or need-based, approach to equity implies, as (Lucy, 1981, p. 448) notes, 'that unequals should be treated un-equally'. Thus, disadvantaged residents or areas are awarded extra increments of resources, so as to provide these groups with opportunities that they might not otherwise have had.

Therefore, in order to redistribute GPSs in a compensatory manner it is important to assess "Who gets what?" or, normatively, "who ought to get what?" (Wicks and Crompton, 1986: 342). The analysis presented in this article identified "disadvantaged" populations based on socio-economic characteristics of age, income, population density, and area of residence. While comparing the poorest (Iztapalapa) and wealthiest (Miguel Hidalgo) boroughs in Mexico City a series of steep socio- environmental differences are observable. For instance, Miguel Hidalgo, a borough with a relatively small size $\left(26,96 \mathrm{~km}^{2}\right)$, medium population density, very low poverty levels and a highly-educated population hosts 197 GPSs. Conversely, Iztapalapa, a larger borough in size $\left(117 \mathrm{~km}^{2}\right)$ with the highest population density in the entire Federal District, very high levels of poverty and ruinous lack of access to basic social services accounts for 133 GPSs.

In addition, taking into account the PNI analysis done for the entire city (table 3 and map 6), Iztapalapa and Miguel Hidalgo are almost exact opposites while compared. On the one hand, Miguel Hidalgo presents a low to very low need of parks per census tract. On the other hand, Iztapalapa presents a high to very high need of parks per census tracts in the large majority of its area. However, it is noticed that even in Miguel Hidalgo the need of parks is ample. From a total of 11 census tracts, 109 (93\%) were graded as having a very high need of parks and only two 
$(1.7 \%)$ were graded in low or very low need of parks (map 3 and map 4). Even the wealthiest borough of the city presents a severe concentration of parks biased against populations with substandard socio-economic characteristics. In this regard, Iztapalapa presents the worst condition (map 5 and map 6); from a total of 512 census tracts, 425 (83\%) were graded as in very high need of parks and only five $(0.9 \%)$ census tracts were graded as low. Considering that populations with a substantially higher level of pauperization (table 4) should be targeted as priority groups to be served, park inequality in Mexico City is extreme.

\section{Map 3}

Miguel Hidalgo levels of poverty and distribution of GPSs

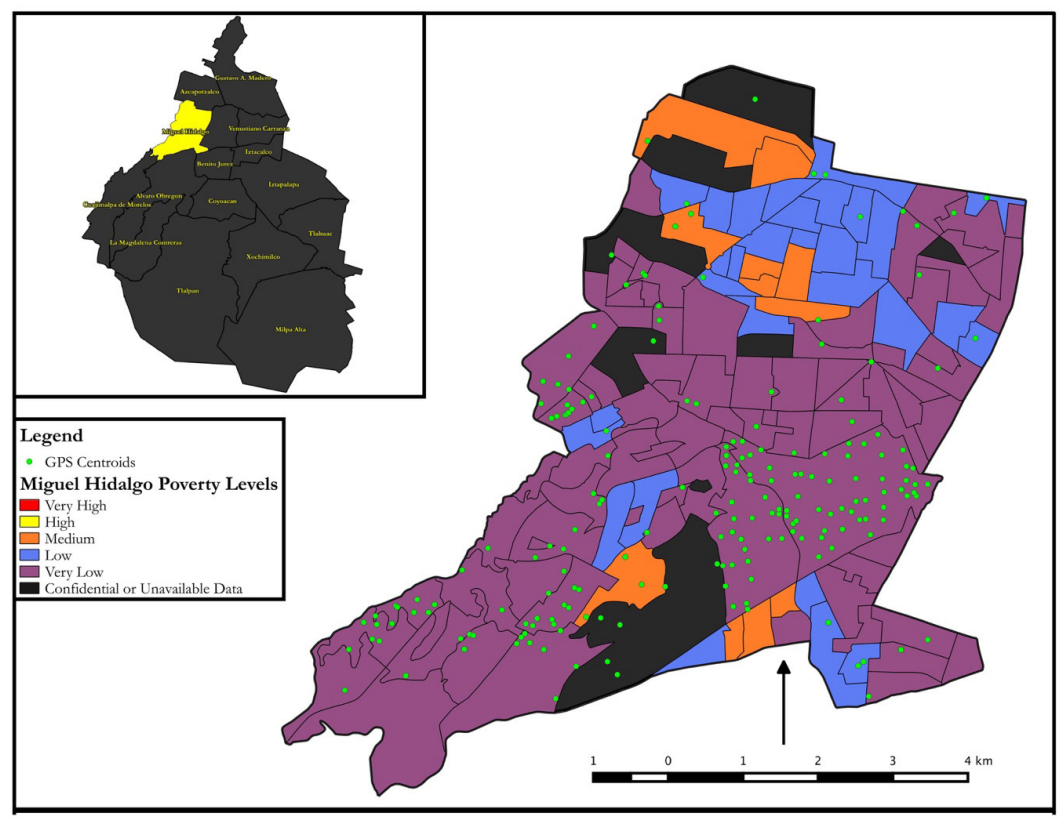

Source: Author's elaboration, 2015. 


\section{Map 4 \\ Miguel Hidalgo park need index (PNI)}

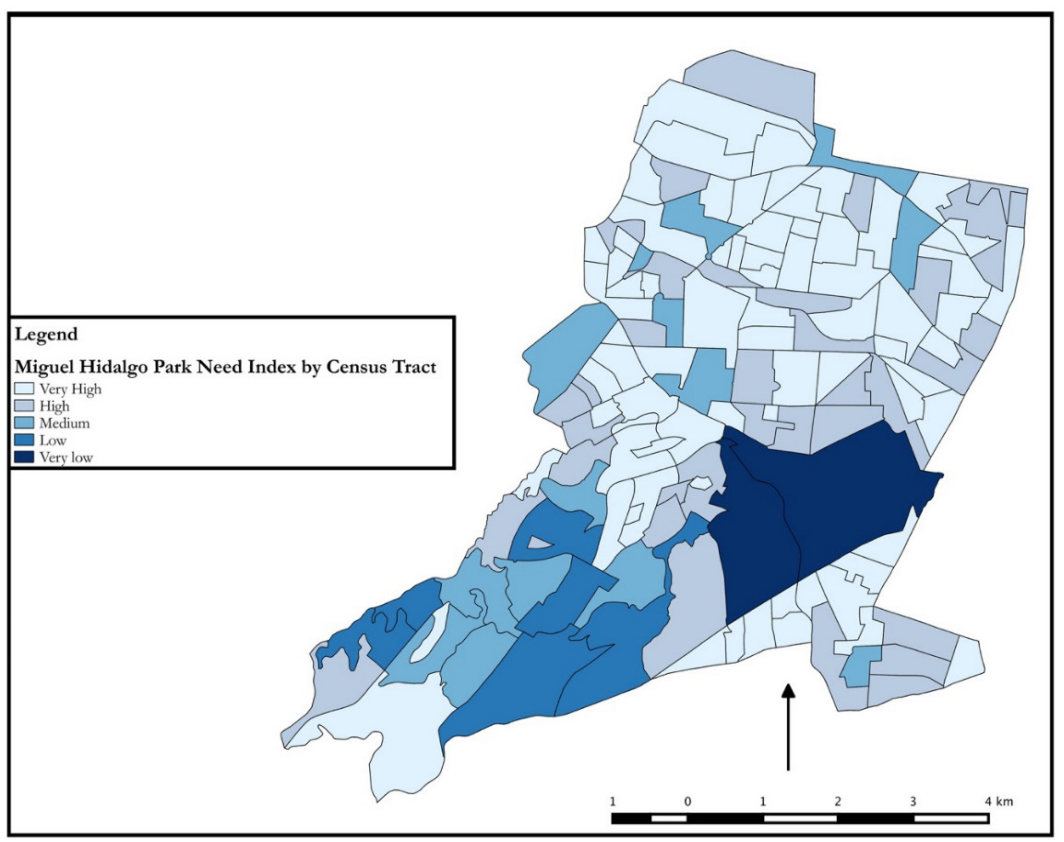

Source: Author's elaboration, 2015.

Map 5

Iztapalapa levels of poverty and distribution of GPSs

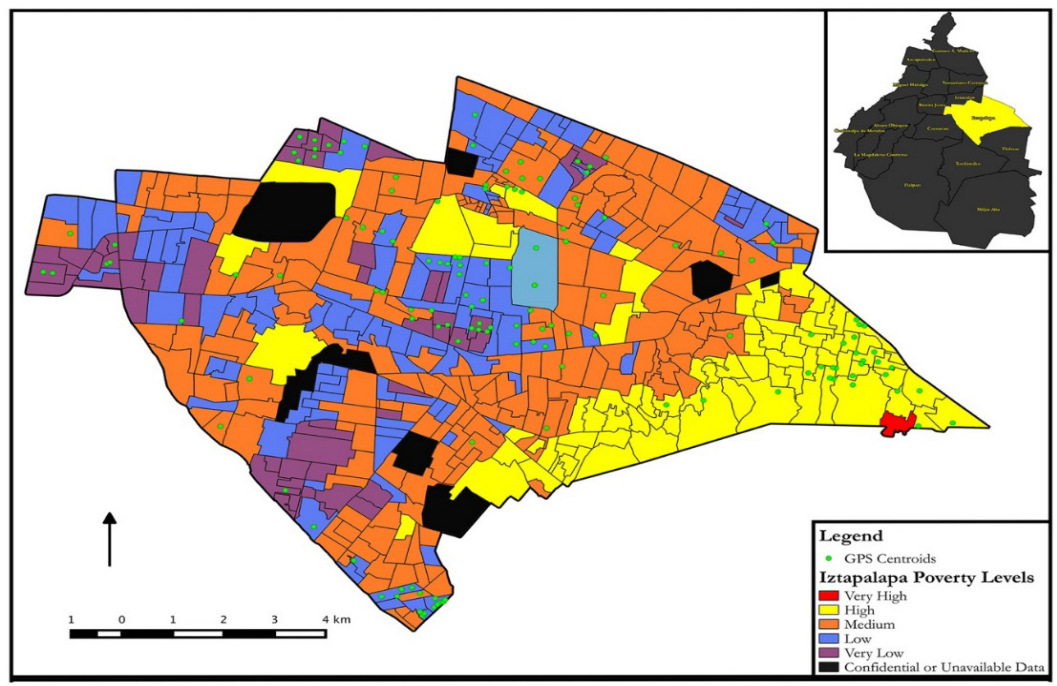

Source: Author's elaboration, 2015. 


\section{Map 6 \\ Iztapalapa park need index (PNI)}

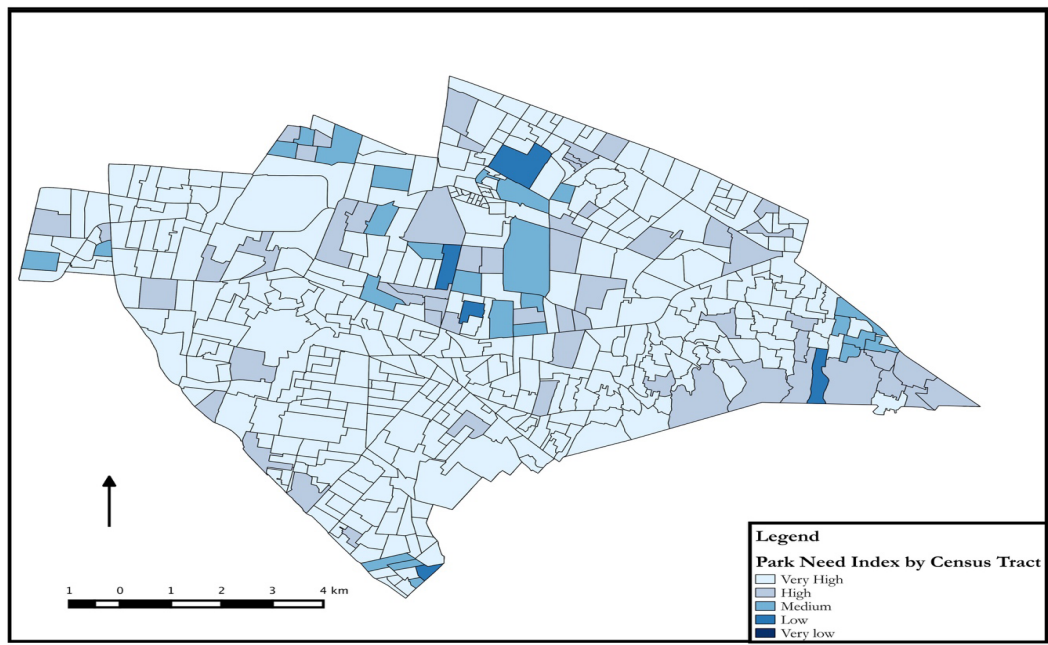

Source: Author's elaboration, 2015.

Table 3

Park need index distribution by census tracts

\begin{tabular}{|c|c|c|c|c|c|c|}
\hline & \multicolumn{4}{|c|}{ Park need index for Mexico City by census } & \multirow[b]{2}{*}{ Low } & \multirow[b]{2}{*}{ Very low } \\
\hline & $\begin{array}{l}\text { Total Tracts } \\
\text { analyzed }\end{array}$ & $\begin{array}{r}\text { tract } \\
\text { Very high }\end{array}$ & High & Medium & & \\
\hline Mexico City & 2937 & & & & & \\
\hline Azcapotzalco & 124 & 89 & 22 & 13 & --- & $-\ldots$ \\
\hline Coyoacán & 201 & 63 & 58 & 50 & 29 & 1 \\
\hline Cuajimalpa de Morelos & 42 & 31 & 6 & 3 & 2 & --- \\
\hline Gustavo A. Madero & 329 & 295 & 25 & 7 & 2 & --- \\
\hline Iztacalco & 164 & 136 & 21 & 6 & 2 & --- \\
\hline Iztapalapa & 512 & 425 & 57 & 25 & 5 & $-\ldots$ \\
\hline La Magdalena Contreras & 76 & 56 & 16 & 3 & 1 & --- \\
\hline Milpa Alta & 49 & 49 & -- & --- & --- & --- \\
\hline Álvaro Obregón & 251 & 184 & 47 & 14 & 5 & 1 \\
\hline Tlahuac & 144 & 131 & 10 & 1 & 2 & -- \\
\hline Tlalpan & 245 & 163 & 49 & 26 & 7 & -- \\
\hline Xochimilco & 163 & 148 & 7 & 6 & 2 & -.- \\
\hline Benito Juárez & 138 & 100 & 30 & 7 & 1 & --- \\
\hline Cuauhtémoc & 194 & 155 & 29 & 7 & 1 & 2 \\
\hline Miguel Hidalgo & 117 & 109 & 39 & 14 & 7 & 2 \\
\hline Venustiano Carranza & 188 & 141 & 31 & 13 & 3 & --- \\
\hline
\end{tabular}

Source: Compilation and categorization by author, 2015 . 


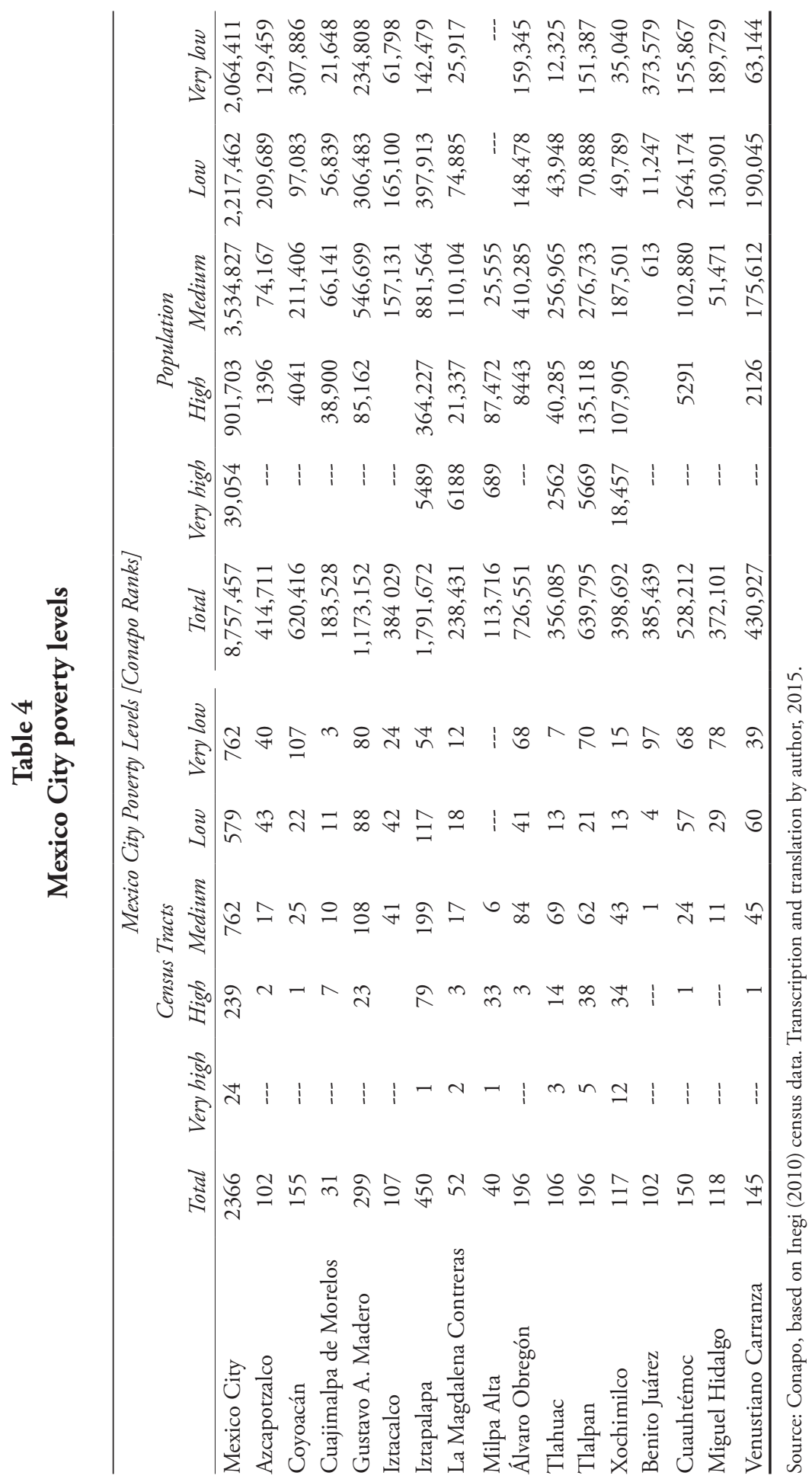




\section{Map 7}

Park need index by census tract for Mexico City and existing parks

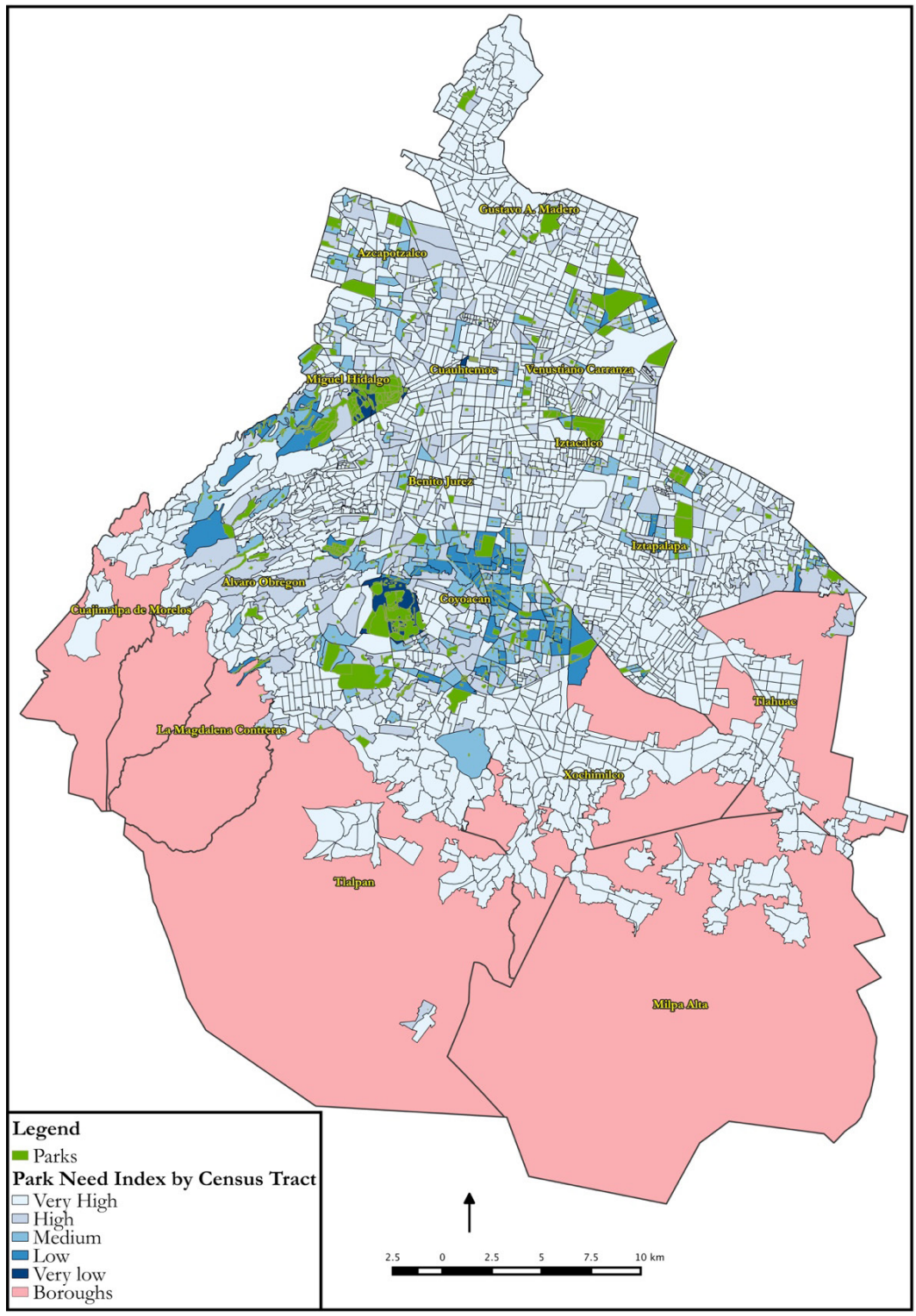

Source: Author's elaboration, 2015. 


\section{Intitutional legacies on the production of GPS}

According to Boone et al., (2009: 777)

a limitation of much environmental justice literature is the inference of process from pattern. Although the distribution of parks or hazardous facilities can suggest possible linkages between race and the location of environmental amenities or disamenities, to advance the science of environmental justice it is necessary to investigate the drivers or forces that generate those pattern.

Such drivers and forcers are embedded within historical processes that have resulted in today's complex reality. Wakild (2007) disentangled the socioeconomic knots interwoven with historical decision-making processes that resulted in the emergence of urban parks in Mexico. According to her research, certain actors playing significant roles during the modernization era of Mexico and concomitantly Mexico City's socioenvironmental urban development, including green space distribution in the city, were determined. For example, Chapultepec Park located next to the Chapultepec Castle - whose construction started in 1785 under the administration of the New Spain's virrey Bernardo de Gálvez in Mexico- evolved to become a space for the dominant classes and was successful in fulfilling economic and political needs.

On the other hand, the Balbuena Garden was designed for the marginal classes of the city, as a celebratory project for the centenary of independence. Against that historical background the emergence of new parks can be analyzed considering the main actors involved in envisioning, developing, and maintaining current urban infrastructure. Such is the case, for example, of the Bicentenario Park, located on the limits of Azcapotazlco and Miguel Hidalgo boroughs. Its very nature is sui generis given its origin as a political and environmental depletion mitigation tool (Fernández-Álvarez, 2012). The park was constructed upon a brown site that worked as one of the largest oil and gasoline refineries in the city for several years. Hence, these examples show the importance of unveiling the underlying historical and recent political, social, and economic factors that could be accountable or connected with the production of the uneven distribution of GPSs in Mexico City. Further research on this matter should be conducted in order to determine the origins and patterns of a seemingly institutionalized GPSs uneven distribution and it its negative bias against marginal populations. 


\section{Conclusion}

Distribution of GPSs in Mexico City is severely biased against marginal populations. Evidence shows that socio-economic characteristics in the Mexican capital are directly related to the number of $\mathrm{m} 2$ of green areas available per person. GPS concentrates in wealthy areas of the city where older, more educated individuals reside. Conversely, densely populated areas with very high levels of poverty are acutely underserved. As explained earlier in this article, parks are the most common form of GPS in Mexico City and its distribution is also linked to population's socioeconomic features. However, even in affluent areas of the city there exists a pronounced need for parks. That is not to say GPS deficit in the Federal District is in any way uniform; in fact, the unequal nature of GPS distribution is palpable and constitutes an undeniable instance of socio-environmental justice. A more sophisticated understanding of GPS equity in the particular context of Mexico City was an urgent scholarly and governmental task needed to advance efforts to reduce the gap between those with and without access to urban nature in the city. Nevertheless, GPS deficit and inequitable distribution cannot be addressed without transforming the structures that produce and perpetuate social and environmental injustices in the first place. Institutions in charge of managing GPS in Mexico City are responsible for a series of procedural injustices that prevent marginal populations of having access to space in the city. In the particular case of parks, the intrusion of private corporations - often in charge of providing financial resources for urban infrastructurehas been a major obstacle for the state to develop and maintain solid urban development projects that benefit those most in need (FernándezÁlvarez, 2012). The structural forces that set and maintain social, political, economic, and cultural relations in urban context must be revised.

Space in Mexico City seems to be following a commodification and privatization trend in favor of a group of national and international corporations seeking financial profit (Aguilar et al., 2003; Delgadillo-Polanco, 2012; Delgado, 2004). The creation and management of the most important GPSs in Mexico City is the result of companies investing private resources with the main objective of financial return prioritized over any environmental, social, or cultural need. This context renders state efforts to govern urban spaces ineffective or inexistent. A central characteristic of GPS in Mexico City is the ubiquitous presence of private capital used for public projects, an oxymoronic dynamic that results in the imposition of agendas established by a reduced group of beneficiaries at the expense of the large majority of the city dwellers. 
Evidence suggest that the Mexican state is no longer independent, it is incapable of controlling public tax resources and its capability to create and maintain meaningful public projects has been severely eroded. For example, as discussed early in this article, the Federal District Environmental Law (FDEL) has been ignored since 2002. According to the FDEL starting in 2002, a yearly report on the evolution of green public spaces was responsibility of each borough in Mexico City aided by the Ministry of the Environment in the Federal District. However, there exist only one inventory of green public space for 2002 and no further account of these areas has been done for the past 12 years.

As proposed by Marxist political ecologists, the political economy of a state has a direct influence in the creation of tensions amongst urban dwellers and their environments (Harvey, 2010; Mitchell, 2003). Moreover, reducing the state participation in governance affairs, such as providing urban amenities, is a quintessential neoliberal goal. In the context of Mexico City and its GPSs, governmental institutions responsible for serving citizens have been substituted for neoliberal forces. Consequently, companies take over urban space and in order to commercialize it as a commodity to be bought by consumers. This insidious practice results in segregation of those individuals that are not capable of affording goods and services that are supposedly paid using tax money. Therefore, GPS deficit in marginal areas of Mexico City is the result of state institutions' incapability to manage resources with a democratic social approach. With the state's abrogation of responsibility, there appears no viable alternative but to succumb to private corporations' impositions in order to obtain resources for public projects. Ultimately, the state's dependence of private capital to secure governance yields uncontrolled corporative intervention. This intervention, as seen with the examined case studies, will inevitably result in replacing of social goals with private financial objectives and the perpetuation of social and environmental injustices.

\section{References}

Aguilar, Adrián Guillermo and Pablo Mateos (2011), "Diferenciación sociodemográfica del espacio urbano de la Ciudad de México", Eure, 37 (110), Pontificia Universidad Católica de Chile, Facultad de Arquitectura, Diseño y Estudios Urbanos Instituto de Estudios Urbanos y Territoriales, Santiago, Chile, pp. 5-30.

Aguilar, Adrian, Peter Ward and C. B. Smith Sr (2003), "Globalization, regional development, and mega-city expansion in Latin America: Analyzing Mexico City's periurban hinterland”, Cities, 20 
(1), University of Washington Tacoma, Tacoma, United States of America, pp. 3-21.

Avilés, Isabel Reyes and Juan José Chaparro-Gutiérrez (2010), "Los servicios ambientales de la arborización urbana: retos y aportes para la sustentabilidad de la ciudad de Toluca”, Quivera, 12 (1), Universidad Autónoma del Estado de México/Centro de Investigación y Estudios Avanzados en Planeación Territorial de la Facultad de Planeación Urbana y Regional, Toluca, México, pp. 96-102.

Aziz, Hazlinda-Abdul and Mohd Hisham-Rasidi (2014), "The role of green corridors for wildlife conservation in urban landscape: A literature review", IOP Conference Series: Earth and Environmental Science, 8th International Symposium of the Digital Earth (ISDE8), August 26-29, 2013, Sarawak, Malasya.

Bigio, Anthony and Bharat Dahiya (2004), Urban environment and infrastructure: Toward livable cities, World Bank Publications, Washington, United States of America.

Bjerke, Tore, Torbjørn Østdahl, Christer Thrane and Einar Strumse (2006), "Vegetation density of urban parks and perceived appropriateness for recreation", Urban Forestry \& Urban Greening, 5 (1), University of Copenhagen, Copenhagen, Denmark, pp. 35-44.

Bolin, Bob, Eric Matranga, Edward Hackett, Edward Sadalla, David Pijawka, Debbie Brewer and Diane Sicotte (2000), "Environmental equity in a sunbelt city: the spatial distribution of toxic hazards in Phoenix, Arizona", Global Environmental Change Part B: Environmental Hazards, 2 (1), University of Melbourne, Victoria, Australia, pp. 11-24.

Boone, Christopher, Geoffrey Buckley, Morgan Grove and Chona Sister (2009), "Parks and people: An environmental justice inquiry in Baltimore, Maryland", Annals of the Association of American Geographers, 99 (4), American Association of Geographers, Washington, United States of America, pp. 767-787.

Bowler, Diana, Lisette Buyung-Ali, Teri Knight and Andrew Pullin (2010), "Urban greening to cool towns and cities: A systematic review of the empirical evidence", Landscape and Urban Planning, 97 (3), 
University of Michigan, Michigan, United States of America, pp. 147-155.

Brownlow, Alec (2006), "An archaeology of fear and environmental change in Philadelphia", Geoforum, 37 (2), Trinity College, Dublin, Irland, pp. 227-245.

Cao, Xi, Onishi Akio, Jin Chen and Imura Hidemufi (2010), "Quantifying the cool island intensity of urban parks using ASTER and IKONOS data", Landscape and Urban Planning, 96 (4), University of Michigan, Michigan, United States of America, pp. 224-231.

Carruthers, David (2008), Environmental justice in Latin America: Problems, promise, and practice, MIT Press, Cambridge, United States of America.

Chiesura, Anna (2004), "The role of urban parks for the sustainable city", Landscape and Urban Planning, 68 (1), University of Michigan, Michigan, United States of America, pp. 129-138.

Conapo (Comisión Nacional de Población) (2010), "Índice Absoluto de Marginación 2000-2010", Secretaría de Gobernación, México, $<$ http://www.conapo.gob.mx/es/CONAPO/Indice_Absoluto_ de_Marginacion_2000_2010>, February 20th, 2015.

Connell, John (1999), "Beyond Manila: walls, malls, and private spaces", Environment and Planning A, 31 (3), University of British Columbia, Vancouver, Canada, pp. 417-439.

Coolidge, Jacqueline, Richard Porter, John Zhang, Lorch Hall and Ellen Maurer (1993), "Urban environmental services in developing countries", working paper 9, Department of Economics, University of Michigan, Ann Arbor, United States of America.

Davis, Mike (1999), Ecology of fear: Los Angeles and the imagination of disaster (1st Vintage Books edition), Vintage, United States of America.

Delgadillo-Polanco, Víctor Manuel (2012), “¿El derecho a la ciudad en la Ciudad de México? ¿Una retórica progresista para una gestión urbana neoliberal?", Andamios, 9 (18), Universidad Autónoma 
de la Ciudad de México/Colegio de Humanidades y Ciencias Sociales, Ciudad de México, México, pp. 117-139.

Delgado, Jorge (2004), “Impacto de la globalización neoliberal en el ordenamiento urbano y territorial”, Papeles de Población, núm. 41, Universidad Autónoma del Estado de México, Toluca, México, pp. 141-167.

Fernández-Álvarez, Rafael (2012), "Neoliberalism and parks: the urban political ecology of green public space in Mexico City", Sociedad Hoy, núm. 23, Universidad de Concepción, Santiago, Chile, pp. 83-115.

Flores-Alanís, Glafiro (2005), "El arbolado urbano en el área metropolitana de Monterrey", Ciencia UANL, 8 (1), Universidad Autónoma de Nuevo León, San Nicolás de los Garza, México, p. 20.

Flores-Xolocotzi, Ramiro, Manuel de Jesús González-Guillén and Héctor Manuel de-los-Santos-Posadas (2010), "Valoración económica del servicio recreativo del parque Hundido de la Ciudad de México", Región y Sociedad, 22 (47), El Colegio de Sonora, Hermosillo, México, pp. 123-144.

Gante-Cabrera de, Victor and Maricela Rodríguez-Acosta (2009), "Parques y jardines del municipio de Puebla", Elementos, núm. 76, Universidad Autónoma de Puebla, Puebla, México, pp. 51-55.

Garvin, Alexander (2011), Public parks: the key to livable communities, Ronda Brands (ed.), W.W. Norton \& Co, New York, United States of America.

GDF (Gobierno del Distrito Federal) (2002), "Ley ambiental de protección a la tierra en el Distrito Federal. Capítulo II, Áreas Verdes", Gaceta Oficial del Distrito Federal, enero 2000, disponible en <http://www.aldf.gob.mx/archivo-3cd1 aa41964e3f9735705a55d1ba096e.pdf>, 20 de enero de 2015.

Hardoy, Jorge, Diana Mitlin and David Satterthwaite (2013), Environmental problems in an urbanizing world: finding solutions in cities in Africa, Asia and Latin America, Routledge, London, United Kingdom. 
Harvey, David (2010), Social justice and the city 1, University of Georgia Press, Georgia, United States of America.

Hernández-Bonilla, Mauricio (2005), "Mejoramiento del espacio público en las colonias populares de México Caso de estudio de Xalapa-Veracruz", Revista INVI, 20 (53), Universidad de Chile/ Facultad de Arquitectura y Urbanismo-Instituto de la Vivienda, Santiago, Chile, pp. 181-199.

Heynen, Nik, Harold Perkins and Roy Parama (2006), "The political ecology of uneven urban green space: the impact of political economy on race and ethnicity in producing environmental inequality in Milwaukee", Urban Affairs Review, 42 (1), University of Illinois, Chicago, United States of America, pp. 3-25.

Inegi (Instituto Nacional de Estadística y Geografía) (2010), "XII Censo de Población y Vivienda 2010", Instituto Nacional de Estadistica $y$ Geografía, Mexico, disponible en <www.inegi.org.mx>, enero 17, 2015.

Janoschka, Michael and Axel Borsdorf (2004), "Condominios fechados and barrios privados: the rise of private residential neighbourhoods in Latin America", Private neighbourhoods: global and local perspectives, Routledge, London, United Kingdom, pp. 89-104.

Kitchen, Lawrence (2012), "Are trees always "good"? Urban political ecology and environmental justice in the valleys of south wales", International Journal of Urban and Regional Research, 37 (6), University of Cambridge, Cambridge, United States of America, pp. 1968-1983.

Loughran, Kevin (2014), "Parks for profit: the high line, growth machines, and the uneven development of urban public spaces", City \& Community, 13 (1), Columbia University, New York, United States of America, pp. 49-68.

Low, Setha, Dana Taplin and Suzanne Scheld (2005), Rethinking urban parks: public space and cultural diversity, University of Texas Press, Austin, United States of America. 
Lucy, William (1981), "Equity and planning for local services", Journal of the American Planning Association, 47 (4), University of Texas, Austin, United States of America, pp. 447-457.

Madge, Clare (1997), "Public parks and the geography of fear", Tijdschrift Voor Economische En Sociale Geografie, 88 (3), Utrecht University, Utrecht, The Netherlands, pp. 237-250.

Mier-y-Terán, Arturo, Isabel Vázquez and Alicia Ziccardi (2012), "Pobreza urbana, segregación residencial y mejoramiento del espacio público en la Ciudad de México", Sociologías, 14 (30), Federal University of Rio Grande do Sul (UFRGS), Porto Alegre, Brasil, pp. 118-155.

Mitchell, Don (2003), The right to the city: Social justice and the fight for public space, Guilford Press, New York, United States of America.

Nicholls, Sarah (2001), "Measuring the accessibility and equity of public parks: a case study using GIS”, Managing Leisure, 6 (4), University of Stirling, Stirling, Scotland, pp. 201-219.

Oliffe, John and Lorraine Greaves (eds.) (2011), Designing and Conducting Gender, Sex, and Health Research, Thousand Oaks: SAGE Publications Inc., United States of America.

PAOT (Procuraduría del Ordenamiento Territorial) (2010), "Presente y futuro de las áreas verdes y del arbolado de la Ciudad de México", Gobierno del Distrito Federal, México.

Pincetl, Stephanie and Elizabeth Gearin (2005), "The reinvention of public green space”, Urban Geography, 26 (5), McGill University, Montreal, Canada, pp. 365-384.

Pincetl, Stephanie (2003), "Nonprofits and park provision in Los Angeles: An exploration of the rise of governance approaches to the provision of local services", Social Science Quarterly, 84 (4), University of Oklahoma, Oklahoma, United States of America, pp. 979-1001.

Rivas-Torres, Daniel (2005), "Planeación, espacios verdes y sustentabilidad en el Distrito Federal", tesis de doctorado en Estudios Urbanos, Universidad Autónoma Metropolitana, Azcapotzalco, Ciudad de México, México. 
Rodgers, Dennis, Joe Beall and Ravi Kanbur (2012), Latin American urban development into the twenty first century: towards a renewed perspective on the city, Palgrave Macmillan, United States of America.

Samara, Tony Roshan, Shenjing He and Guo Chen (2012), Locating right to the city in the global south, Routledge, London, United Kingdom.

Satterthwaite, David (2003), "The links between poverty and the environment in urban areas of Africa, Asia, and Latin America", The Annals of the American Academy of Political and Social Science, 590 (1), The American Academy of Political and Social Science, Philadelphia, United States of America, pp. 73-92.

Schlosberg, David (2004), "Reconceiving environmental justice: global movements and political theories", Environmental Politics, 13 (3), University of Kent, Catenbury, United Kingdom, pp. 517-540.

Schteingart, Martha (1989), "The environmental problems associated with urban development in Mexico City", Environment and Urbanization, 1 (1), International Institute for Environment and Development, London, United Kingdom, pp. 40-50.

Schweitzer, Lisa and Max Stephenson (2007), "Right answers, wrong questions: environmental justice as urban research", Urban Studies, 44 (2), Manchester Metropolitan University, Manchester, United States of America, pp. 319-337.

Sister, Chona, Jennifer Wolch and John Wilson (2009), "Got green? addressing environmental justice in park provision”, GeoJournal, 75 (3), The Ohio State University, Ohio, United States of America, pp. 229-248.

Symons, John (1971), "Some comments on equity and efficiency in public facility location models", Antipode, 3 (1), Antipode Foundation, Institute for the Geographies of Justice, London, United Kingdom, pp. 54-67.

Talen, Emily (2010), "The spatial logic of parks", Journal of Urban Design, 15 (4), University of Nottingham, Nottingham, London, pp. 473-491. 
Tortolero, Alejandro (2000), El agua y su historia: México y sus desafíos hacia el siglo XXI, Siglo XXI, México, México.

Turner, Robin and Diana Pei Wu (2002), "Environmental justice and environmental racism. An annotated bibliography and general overview, focusing on U.S. literature, 1996-2002", Berkeley Workshop on Environmental Politics, Institute of International Studies, University of California, Berkeley, United States of America.

Wakild, Emily (2007), "Naturalizing modernity: urban parks, public gardens and drainage projects in porfirian Mexico City", Mexican Studies/Estudios Mexicanos, 23 (1), University of California, Oakland, Unites States of America, pp. 101-123.

Walker, Gordon (2009), "Beyond Distribution and Proximity: Exploring the Multiple Spatialities of Environmental Justice", Antipode, 41 (4), Antipode Foundation, Institute for the Geographies of Justice, Manchester, London, pp. 614-636.

Wicks, Bruce and John Crompton (1986), "Citizen and administrator perspectives of equity in the delivery of park services", Leisure Sciences, 8 (4), University of Waterloo, Waterloo, Canada, pp. 341-365.

Recibido: 25 de agosto de 2015. Corregido: 11 de abril de 2016. Aceptado:17 de junio de 2016.

Rafael Fernández-Álvarez. Doctor en ciencias socioambientales por la Universidad Estatal de Arizona, Estados Unidos y maestro en gestión ambiental por la Universidad de Newcastle, Australia. Actualmente se desempeña como investigador en la School of Human Evolution and Social Change de la Universidad Estatal de Arizona, además de colaborar como editor asociado de la revista científica Polibotánica del Instituto Politécnico Nacional. Sus líneas de investigación incluyen política ecológica, justicia ambiental, análisis socioespacial urbano y sostenibilidad urbana. En 2016 fue nombrado candidato a investigador por el Sistema Nacional de Investigadores México. Entre sus publicaciones recientes: "Neoliberalism and parks: the urban political ecology of green public space in Mexico City", Sociedad Hoy, núm. 23, Universidad de Concepción, Santiago, Chile, pp. 83-115 (2012); en coautoría: "Adapting to risk 
and perpetuating poverty: Household's strategies for managing flood risk and water scarcity in Mexico City", Environmental Science \& Policy, núm. 66, Elsevier, pp. 324-333 (2016). 